\title{
BRITISH JOURNAL PRICING: ENIGMA VARIATIONS, OR WHAT WILL THE U.S. MARKET BEAR?
}

\author{
ROBERT L. HOUBECK, Jr. \\ Head \\ Serials Division \\ University of Michigan Library \\ Ann Arbor, Michigan 48109
}

\begin{abstract}
Dissatisfied with the usual explanations British publishers have offered for the large price differentials between their U.K. and U.S. customersexplanations such as increased distribution costs and currency fluctuations-the author examined 108 journals published by seven major British publishers. He compared their U.K. and U.S. prices and price differentials against four "value indicators": local use, citation frequency, a listing in Katz's Magazines for Libraries, and OCLC holding libraries. He has found that high prices and high price differentials correlate with high indicators of use/value. He concludes that the data suggest that British publishers are pricing their journals in the U.S. market according to what that market is apparently willing to bear. He further suggests that the challenge for libraries arising from this pricing strategy is to identify on-going mechanisms for measuring value against price, in order to ensure that the price any publisher demands for a title corresponds to the value delivered.
\end{abstract}

Musicological sleuths have long since identified the 13 friends whom Sir Edward Elgar portrays in his Enigma Variations. The larger theme in that composition, though, which "through and over the whole set [of variations] 'goes,' but is not played," has proven more elusive. That theme has never been identified.

In the matter of British periodical pricing, the fate of the enigmas has been similar but reversed. The reasons for the specific differential between the U.K. and the U.S. price assigned to any particular journal remains and may always remain - to all, that is, but the publishers - a mystery. [1]. Why is this title priced $59 \%$ above the U.K. rate, why is that title $69 \%$ ? The larger theme, though, which 'goes' but is rarely admitted, can be discerned with precision. Dr. Johnson, two centuries ago, described that theme: "No shopkeeper sells a yard of ribband for sixpence when the current price is seven." At least some British publishers are acting very like Johnson's ribband merchants. They possess products that are in demand and they are pricing those products accordingly. 
Exactly why these publishers have been unwilling to acknowledge that they are acting in accord with this fundamental economic tactic is in itself a tantalizing enigma. But, admit it or not, the reasons for charging U.S. institutional customers, for the same journals, substantially more than equivalent U.K. subscribers are not difficult to discern.

Those reasons are not, at least primarily, the reasons publishers seem ready to recite. Postage and shipping to the U.S. is one such reason. The postage and shipping charges which American publishers add to their overseas subscriptions, when such charges are added at all, appear to increase the prices of American journals sold overseas by $10-15 \%$. The average 1985 markup on the British titles we have examined, on the other hand, was a hefty $66 \%$. If shipping indeed warrants that sort of markup, American libraries might better buy a 747 and ship the titles themselves.

Even if by some miracle American librarians were able to get together and buy that 747 , though, at least some British journal publishers would be unlikely to find that an acceptable alternative. These publishers, curiously, have become alarmed that some American libraries have been "avoiding" paying those higher U.S. prices. That is why many of them have been insisting that British subscription agents begin to identify the final destination of each subscription, even when the agent receives and reships the titles himself. In fact, what one suspects is that the revenues publishers are "losing" by our practice of purchasing British titles through British agents at British prices are not revenues designed primarily to cover the costs of distribution.

This suspicion has been strengthened in our minds by the unspoken but real information conveyed by the prices British publishers are charging their U.K. and non-U.S. overseas customers. We know from a 1981 Royal Society study [2] that Britain accounts for $15 \%$ of total sales of British scholarly journals, that the U.S. market accounts for another $35-40 \%$, and the remaining $50-55 \%$ of sales made elsewhere overseas. Let us assume that this general distribution holds for most major British journal publishers. Most publishers charge their nonU.S. overseas subscribers either the same price as their U.K. customers, or a price 10-20\% above the U.K. rate. Those lower prices-that is, the prices publishers charge to $60-65 \%$ of their customers-speak clearly. They tell us the price at which the publisher can meet his costs and realize some profit. [3] The higher U.S. prices, in that context, tell us quite explicitly why British publishers are alarmed when American subscribers "avoid" paying those inflated publisher-assigned American prices.

Nor have we been satisfied with the explanation that U.S. prices are higher because publishers fear fluctuations in the pound. Indeed, the direction of the pound in recent years has been downward against the dollar, though never more than 15-16\% in any January-December period. [4] Moreover, those American libraries which buy either directly from the publisher or through an American agent pay, not in pounds, but in dollars. If a publisher's intent is to make about the same margin of profit on a title sold in the U.S. in dollars as on a title sold elsewhere in pounds, given the downward direction of the pound that prevailed in the 1984-85 period, there was simply no justification for charging U.S. customers who paid in dollars an average rate of $£ 1.00=\$ 2.30$ when the pound's actual value at the time 1985 prices would have been set (May-June 1984) was in the range of $\$ 1.40$. In those circumstances, when the pound did drop even further against the dollar, margins on titles paid in pounds would have dropped but margins on titles paid in dollars would have increased, even had American subscribers been paying rates closer to $\$ 1.40$ than those they were actually paying. Again, publishers' pricing strategies strongly suggest that they have not been motivated primarily by a desire to protect themselves from wide fluctuations in the value of the pound, nor have they been interested in making the same margins on U.S. sales as they realize on domestic and other foreign sales. 
The standard explanations, then, that British publishers offer for the substantial differentials demanded of American libraries simply fail to convince. Much more likely because more natural has seemed to us the explanation which, in any other context, would seem too obvious to need stating: that British publishers are pricing their products in their various markets in the same way other ordinary businesses price theirs, that is, according to what each market will bear.

And why will the U.S. market bear these high differentials? Why will we pay more for the same products than other world customers? In part, no doubt, because we can pay more. In part, too, surely, because we find it wrenching to break subscription runs. But mainly, we suggest, because British publishers have done their marketing homework. Of the titles we have examined, high price differentials (i.e. $30 \%+$ above the U.K. price) correlate strongly with high indicators of use/value. British publishers are marketing strong products for which, not surprisingly, they are charging strong prices. They are charging - and American librarians are paying-Wedgwood prices for products that are, arguably, Wedgwoods. Given this pricing strategy, librarians indignant at high differentials and itching to respond with large-scale cancellations would have a tough time scratching that itch.

To test this suspicion that British publishers have set high differential rates on titles American libraries would be least likely because least willing - or able - to cancel, we began by identifying from an initial local study and from Hamaker and Astle's investigations [5] seven major British publishers whose journals exhibited large differences between U.K. and U.S. price. These publishers were: Biochemical Society; Basil Blackwell; Butterworths; Cambridge University Press (CUP); Longmans; Oxford University Press (OUP); and Taylor \& Francis. We then identified as many of the periodicals of these publishers to which we subscribed as time and resources permitted. This search produced 108 titles. Price differentials for these 108 titles ranged from $16 \%$ above the U.K. price to $114 \%$. The average U.S. price for these titles exceeded the average U.K. price by $66 \%$.

We then measured these 108 titles against four variables that we expected would give us indications of a title's "value": (1) local use; (2) citation frequency (i.e. the number of times articles in a journal are cited in other articles) [6]; (3) the number of OCLC holding libraries [7]; and (4) a listing in the latest edition of Katz's Magazines for Libraries. [8] We obviously lacked key marketing information available to the individual publishers, data such as their U.K. production costs or breakdowns of subscriptions by country and by institutional/individual subscriber. We recognized that we would thus not be able to discern for any given title why the publisher had decided upon a particular U.K. and U.S. price, and hence a particular differential. We did expect, though, that these four variables would provide broad comparative indicators of a title's value to patrons and scholars, extent of U.S. institutional market penetration, and name recognition or prestige.

Using these four indicators, we wanted to know how many of the 108 titles in our pool met how many of the following "value criteria": (1) medium or high local use; (2) a citation frequency within the first or second quartile (i.e. the upper half) of all Science Citation Index (SCI)/Social Science Citation Index (SSCI)-tracked titles; (3) holdings in at least 202 OCLC libraries (i.e. the average number of OCLC holding libraries for all 108 titles); (4) inclusion of the title in Katz. (See the Appendix tables for a list of these 108 titles, along with prices, differentials, and variables met).

To be sure, each of these criteria, taken individually, are fairly blunt instruments. Citation frequency, for example, as reported in ISI's SCI/SSCI Journal Citation Reports 1984, needs to be used with considerable caution. Taken together, though, these four criteria have enabled us to make, even if in a rough way, "value" comparisons between titles published by the same or one of the other six publishers. 
Both the aggregate data and the data from individual publishers which we have gathered from these 108 titles tends to confirm our suspicion that British publishers have set high differential prices on strong titles. The data also suggests that many of the titles which, according to our criteria, are stronger tend also to bear somewhat higher differentials than the less strong titles.

In Table 1 we see that 85 , or nearly $80 \%$, of the titles we examined met multiple value criteria. The average markup on these titles was $68 \%$. The average markup on the 23 titles meeting none or only one of our four criteria was $58 \%$ - not a staggering difference, but an intriguing one.

The 85 titles meeting two, three, or four criteria exhibited, on average, significant local use. They tended to be cited more frequently than titles meeting fewer of our criteria. They were also more likely to be acknowledged, in one of the basic lists of "best and most useful" English-language titles, as being key journals in their fields. These titles were also much more widely held than titles scoring less well against our criteria.

High-scoring titles, too, tended to differ noticeably from lower-scoring titles in the areas of costs and revenues generated. The 85 high-scoring titles were priced in 1985, on average, $14 \%$ higher $(\$ 176.30 \mathrm{v}$. $\$ 150.78$ ) than titles scoring comparatively less well. They also generated, per individual U.S. institutional subscription, on average, a greater amount of revenue than did lower scoring titles ( $\$ 67.78$ above the U.K. subscription price v. $\$ 56.78$ above).

If one assumes that the number of OCLC holding libraries can give us a rough indication of the distribution of a publisher's U.S. institutional subscriptions (that is, that Title A has twice as many U.S. subscribers as Title B), one can also estimate the comparative U.S. revenues each title might tend to produce. To derive such a figure for any given title, one calculates first the title's average dollar markup over the U.K. price. One then multiplies this figure by the number of OCLC libraries holding that title. When we did the math for these 108 titles, we found that the stronger titles would have tended to generate, on average, two and one-half times more revenue on U.S. sales than might have been generated by titles meet-

TABLE 1

SUMMARY DATA ON SELECTED BRITISH JOURNALS

\begin{tabular}{lcc}
\hline & $\begin{array}{c}\text { Titles Meeting } \\
2,3 \text { or } 4 \\
\text { Value Criteria }\end{array}$ & $\begin{array}{c}\text { Titles Meeting } \\
\text { 0 or 1 } \\
\text { Value Criteria }\end{array}$ \\
\hline Number of titles & 85 & 23 \\
$\begin{array}{l}\text { Avg. difference between U.K. \& U.S. price (1985) } \\
\text { Percent of titles exhibiting medium-to-high local use }\end{array}$ & $68 \%$ & $58 \%$ \\
Percent of titles with citation frequencies in 1st or & 83 of 84 & 11 of 20 \\
$\begin{array}{l}\text { 2nd quartiles among titles tracked by SCI/SSCI } \\
\text { Percent of titles listed in Katz }\end{array}$ & 48 of 60 & 0 of 11 \\
Avg. number of OCLC holding libraries, per title & 67 of 85 & 3 of 18 \\
Avg. U.S. subscription price & 228 & 105 \\
Avg. amount paid by U.S. libraries, per title, above & $\$ 176.30$ & $\$ 150.78$ \\
the U.K. price (per individual subscription) & & $\$ 56.78$ \\
Avg. estimated amount paid by OCLC libraries, per & $\$ 67.78$ & $\$ 5,987$ \\
title, above the U.K. price* & $\$ 15,439$ & \\
\hline
\end{tabular}

"Total OCLC subscriptions in our sample multiplied by the average amount paid by U.S. libraries, per title, over the U.K. price. 
ing fewer of our criteria. The average aggregate difference was $\$ 15,439.25$ per strong title $v$. $\$ 5,986.76$ per lower-scoring title. This pattern held for each publisher's list, except Butterworths'.

These specific dollar figures, of course, are simply indicative. Clearly, we have no access to any publisher's U.S. circulation figures. If OCLC holdings, though, do tend to reflect a publisher's U.S. subscription distribution, we can gain some insight into variations in differentials. Somewhat lower differentials on titles with higher sales can tend to generate as much or more revenue than higher differentials on titles with lower overall U.S. sales. Hence, we need not expect to see a neat correspondence between high differentials and high value indicators. We should, though, expect to find that strong titles-those which are used more heavily, cited more frequently, and are more highly esteemed in the judgment of experts will be more widely held, will command higher prices, and hence will tend to generate more revenue than less strong titles. And that is indeed what the data indicate.

This tendency for stronger titles to bear somewhat higher differentials was also marked in the case of two of our criteria taken separately. The 46 titles which ranked in citation frequency in the first or the second quartiles of the SCI/SSCI Journal Citation Reports tables were priced an average $71 \%$ above the U.K. price. The 24 titles ranked in the third or the fourth quartiles were priced $52 \%$ above the U.K. price. Similarly, the 95 titles exhibiting medium to high local use bore average differentials of $67 \%$; the 10 titles on our list which exhibit low local use bore differentials of a still high but comparatively lower $52 \%$.

This tendency appeared, too, when we examined titles by subject. In Table 2 we clearly see that, for the 18 titles in our pool that are held by our Engineering-Transportation Library, higher use correlates strongly with higher differential rates - and with higher prices, too. The nine highest priced titles have a differential rate of $86 \%$ above the U.K. price; the nine lowest priced titles have a much lower (though still high) $57 \%$ differential. In the case of these titles, at least, it would seem that publishers recognize the relation between value and price and have set their rates accordingly. Those nine highest priced titles, too, one might note, meet an average of 2.1 of our value-criteria; the nine lowest priced meet, on average, only 1.0 . This table also illustrates well the danger of focusing solely on price in isolation from various indicators of use or "value." A title that costs $\$ 735$ but gets 290 uses can be construed as costing, for that year, only about $\$ 2.54 /$ usc. On the other hand, a less expensive but also much less used title may be, per use and for that year, 10 or 12 times more expensive, which is another way of saying that librarians need to consider with caution the variety of ways in which useand value-might be measured.

Of the eight titles that failed to meet any of our criteria, four were relative newcomers which in any case could not have met one of our criteria (inclusion in Katz, which appeared before they were published) and could have met two others only with difficulty (a more than average number of OCLC holding libraries and a citation frequency ranking in SCI/SSCI's Journal Citation Reports, which require three years of data on a title in order to calculate a ranking). These recent titles are Journal of Garden History (Taylor \& Francis, 1981-, 52\%0 above the U.K. rate); Bioessays (CUP, 1984-, 53\% above); British Journal of Music Education (CUP, 1983-, 56\% above); and Laser \& Particle Beams (CUP, 1983-, 79\% above). A fifth recent title which met just one of our criteria was Behavior and Information Technology (Taylor \& Francis, 1982-, 56\%). It is, however, worth noting that apart from Laser \& Particle Beams, which is a title covering a growth-area in the U.S. research community, the price differentials for the other four recent titles, though high, are in fact in each case well below the average U.K./U.S. price differential for the other more established titles published by each firm. This is precisely the sort of pricing pattern one would expect to see in each case. 
TABLE 2

SELECTED BRITISH TITLES HELD BY U-M ENGINEERING-TRANSPORTATION LIBRARY

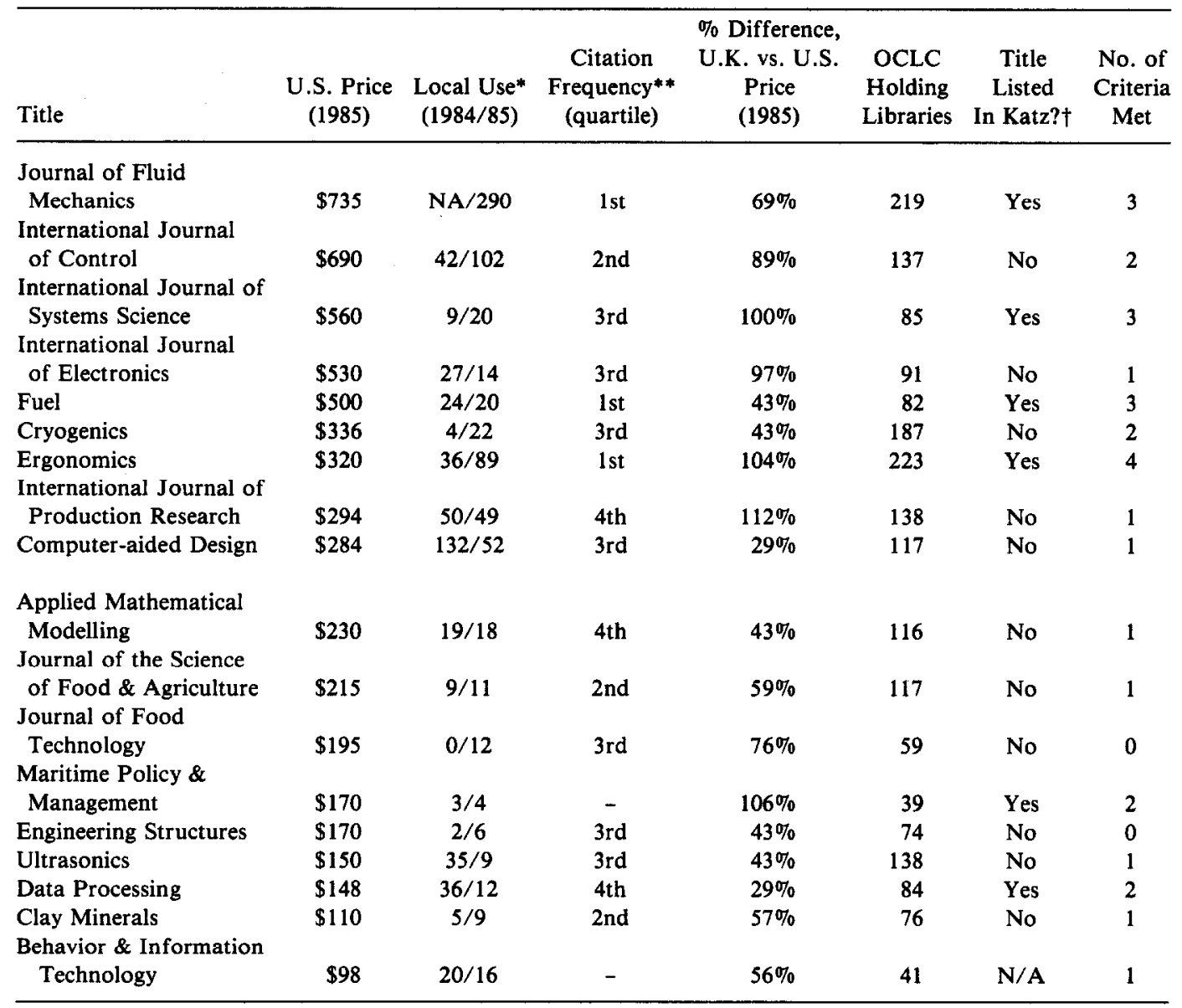

*Bound/unbound reshelving statistics.

${ }^{* *}$ Citation frequency: drawn from Science Citation Index and Social Science Citation Index, Journal Citation Reports 1984. Cited here are quartile rankings (i.e. 1 st $=$ articles in this journal were cited during 1984 in other articles as frequently as articles in one-quarter of all journals tracked by SCI/SSCI; etc.)

$\dagger$ Katz, William A. Magazines for Libraries. New York: Bowker, 1982, 4th ed.

One can perform on the data other calculations that will confirm these patterns wherein stronger titles tend to bear somewhat higher differentials and tend as well to generate-again, if our OCLC variable gives us an accurate picture of U.S. subscription distribution for each publisher's list - considerably more U.S. revenue than titles scoring less well. One can, for example, using that OCLC variable, project the comparative amount of U.S. revenue that each title might have generated. One can then divide each publisher's list in half, comparing the estimated top revenue earners against the bottom earners. For each publisher, one would find that the average amount of U.S. revenue, per individual subscription and per all sub- 
scriptions, is greater for titles scoring higher against our criteria. In the case of three publishers - Taylor \& Francis, CUP, and Longmans - when examined from this perspective, stronger titles tended also to bear somewhat higher differentials. Differences between top revenue-generators and bottom revenue-generators were, respectively, $93 \%$ vs. $77 \%, 74 \%$ vs. $65 \%$ and $49 \%$ vs. $39 \%$.

The data we have gathered thus far in our investigations are not conclusive. Some of our indicators - such as our citation frequency variable, for example-need refinement. Moreover, to get a complete picture, one ought to examine all the titles on a publisher's list. Still, the data - and common sense - does suggest we are looking in the right direction. Specifically, the data strongly suggests that some British publishers are setting very high differential rates in the U.S. market on what are very strong titles. In this way they are able to realize higher revenues per title from their U.S. sales than they would derive were U.S. libraries paying either their general overseas rates or, where separate overseas rates are not quoted, the U.K. rate. At the same time, by setting those higher differentials on relatively stronger titles, publishers effectively minimize the risk of cancellations. The pricing strategy which CUP and Taylor \& Francis appear to be following on new titles, where these titles are priced in the U.S. at rates below their "fleet average" differential for more established titles, tends also to support this surmise. Finally, the data also suggests that, although virtually all the titles examined bore "high" differentials, the higher differentials tended to be attached to the stronger titles.

One needs to add some cautions to this latter point. The highest differentials do not in every case correspond to high indicators of value; nor do (relatively) lower differentials always correspond to low use or low citation frequency or to few holding libraries. Keesings, on the Longmans list, at $83 \%$ above the U.K. price meets four of our criteria and is clearly a central title by any measure. Yet Longmans in 1985 priced the equally key English Historical Review at only (!) $36 \%$ above the British market. Still, even at one-third the price of Keesings and with that lower differential, based on its probably wider U.S. circulation, we estimate that $E H R$ might have generated in the U.S. market nearly half as much revenue as the title bearing the higher differential.

Clearly, one ought not to press variations among absolute differentials too hard. Differentials, after all, tell us as much about the British as about the U.S. price. Public Administration, for example, met only one of our criteria yet in 1985 was priced $89 \%$ above the U.K. price. From OCLC, we assume that comparatively few U.S. libraries hold the title. Yet this title has by far the highest total circulation (as reported in Ulrich's) of any title on our Blackwell list. Its circulation, one might speculate, may well be relatively wider among British libraries; the title may even be targeted principally to the U.K. and Commonwealth market. Many of its articles deal with aspects of British politics and government. Moreover, its overseas rate is significantly lower than the rates of the other Blackwell titles we examined (9\% above the U.K. price v. $20-25 \%$ for the other titles). Blackwell's, then, may be pricing Public Administration primarily for its domestic and non-North American market. Hence the high differential might in this case be the result, not of a desire to extract from American librarians the last possible farthing, but rather of a recognition of this title's limited ability to penetrate the U.S. market coupled with a desire on the part of Blackwell to keep its price in Britain and in some Commonwealth markets attractively low. Particular differentials, then, are surely as conditioned by the U.K. as by the U.S. market. All of which, though, still leaves unanswered the question: Why price this title to those fewer U.S. subscribers $89 \%$ above that lower U.K. price? Other overseas customers pay only $£ 2.50$ more than British customers. U.S. subscribers pay an average $\mathbf{2} 24$ more. 
If it would be a mistake to focus too narrowly on specific differentials between particular titles, U.S. librarians, reflecting on the overall magnitude of the differentials and the high quality of the titles to which they are attached, can legitimately surmise that many British publishers have targeted their strongest titles for high, if not always the highest, differentials. After all, of the 108 titles we examined, $103(95 \%)$ were in 1985 priced at least $30 \%$ above the U.K. price; $96(89 \%)$ were priced at least $40 \%$ above the U.K. rate; $84(78 \%)$ were priced at least $50 \%$ above the U.K. rate. If the U.K. price for a title tells us what is at least the publisher's break-even price, those high U.S. differential rates in turn indicate the sort of profit margins British publishers are realizing from their U.S. sales.

It would be a mistake, too, to regard the mere narrowing of these differentials as a sign of "victory" for the American library community. Those rates could be narrowed by a lowering of the U.S. price - which will not happen, at least not without some dramatic action by American institutional consumers. They could be narrowed, as Taylor \& Francis has been narrowing its 1986 differentials, by a rise in the British price - which is no service to our British colleagues who are also struggling to keep their patrons supplied with ready access to these same research publications. Similarly, a single price for the entire world would have the same negative effect upon British libraries (not to mention the libraries of far less affluent parts of the world) with no corresponding advantage to us. The single world price, we may be certain, would be the higher U.S. price, not the lower British.

More than bare price differentials between countries, our data indicate that American librarians ought to be taking a second look at the actual prices we are being charged for British journals. Those prices suggest that we may need to become more alert - and discriminating consumers. Consider, for example, one of those anomalies on our list, Taylor \& Francis' History of Education. This title failed to meet our value criteria in a single category. Its 1985 issues cost U.S. libraries a hefty $112 \%$ above the price charged U.K. subscribers. But even more surprisingly, those issues cost U.S. libraries $\$ 131.00$. Now, according to Horn and Lenzini, [9] the average 1985 U.S. education periodical costs only $\$ 37.81$. History of Education may well be a better title than the average U.S. education periodical. Still, rather than focusing only on that $112 \%$ differential, American librarians ought to be asking how they might go about deciding whether this title is worth $247 \%$ more than the average U.S. education periodical. This question of worth - to whom and by what measures - is one of the key questions raised by this phenomenon of differential pricing.

In Table 3 we set out the results of a spot comparison of 1985 U.S. prices for various categories of British journals versus the average 1985 prices for U.S. periodicals in the same subject areas. In philosophy and religion, political science, and economics the prices of the British periodicals we examined exceeded those of their average U.S. counterparts by $145 \%, 117 \%$, and $91 \%$, respectively. Clearly, more work needs to be done with these sorts of comparisons. For one thing, we ought to attempt to identify the true peers and the true competitors for each of these titles and compare those prices one with another. Very likely many British journals are far better titles than the "average" U.S. title in the same field. Still, these wide variations in price for journals in the same subject area are worth both further investigation and reflection.

In particular these variations are worth reflection because they point to the question: What for any journal is the upper limit to which its price could rise before librarians would find that its price exceeded its usefulness?

This question, in an institutional setting, where the people who use a journal-and those who will someday use the journal - are not the people who bear the direct costs of that journal, is particularly difficult. Yet, in the light of Table 4, the question for U.S. librarians may well become increasingly apposite. 
TABLE 3

AVERAGE 1985 U.S. PRICES OF SELECTED BRITISH PERIODICALS VERSUS AVERAGE 1985 PRICES FOR U.S. PERIODICALS IN THE SAME SUBJECT AREAS

\begin{tabular}{lcc}
\hline & U.S. Average* & British Average** \\
\hline Philosophy and religion & $\$ 24.30$ & $\$ 70.63$ \\
Political science & $\$ 32.72$ & $\$ 70.14$ \\
Economics & $\$ 44.41$ & $\$ 84.77$ \\
\hline
\end{tabular}

"Horn, Judith G. and Lenzini, Rebecca T., "Price Indexes for 1985: U.S. Periodicals," Library Journal (Aug 1985), p. 54.

**Philosophy \& religion $=11$ titles (Analysis, British Journal of Aesthetics, Journal of Ecclesiastical History, Metaphilosophy, Mind, New Testament Studies, Philosophical Books, Philosophical Quarterly, Philosophy, Ratio, Religious Studies).

Political science $=7$ titles (British Journat of Political Science, Journal of Common Market Studies, Journal of Latin American Studies, Journal of Social Policy, Parliamentary Affairs, Soviet Studies, Studies in Comparative Communism).

Economics $=8$ titles (British Journal of Industrial Relations, Bulletin of Economic Research, Economic Journal, Energy Economics, Journal of Industrial Economics, Oxford Bulletin of Economics and Statistics, Oxford Economic Papers, World Economy).

TABLE 4

PRICE DIFFERENTIALS AND VARIABLE SUMMARIES, BY PUBLISHER

\begin{tabular}{|c|c|c|c|c|c|c|c|c|}
\hline & $\begin{array}{c}\text { No. of } \\
\text { Titles }\end{array}$ & $\begin{array}{c}\text { Avg. } \% \\
\text { Difference, } \\
\text { U.S./U.K. }\end{array}$ & $\begin{array}{c}\text { Avg. U.S. } \\
\text { Price } \\
\text { (1985) }\end{array}$ & $\begin{array}{l}\text { Avg. } \\
\text { Local } \\
\text { Use }\end{array}$ & $\begin{array}{c}\text { Avg. } \\
\text { Quartile } \\
\text { Rank }\end{array}$ & $\begin{array}{c}\text { Avg. OCLC } \\
\text { Holding } \\
\text { Libraries }\end{array}$ & $\begin{array}{c}\text { No. of } \\
\text { Titles } \\
\text { In Katz }\end{array}$ & $\begin{array}{c}\text { Avg. No. } \\
\text { Criteria } \\
\text { Met }\end{array}$ \\
\hline Taylor \& Francis & 19 & $84 \%$ & $\$ 333$ & Medium & 2.0 & 126 & $8^{*}$ & 1.9 \\
\hline Biochemical Society & 4 & $82 \%$ & $\$ 321$ & High & 1.0 & 289 & 3 & 3.5 \\
\hline Basil Blackwell & 16 & $69 \%$ & $\$ 66$ & Medium & $\mathrm{n} / \mathrm{a}^{* *}$ & 196 & 12 & 2.1 \\
\hline Cambridge Univ. Press & 35 & $69 \%$ & $\$ 166$ & High & 1.7 & 233 & $26^{*}$ & 2.9 \\
\hline Oxford Univ. Press & 14 & $55 \%$ & $\$ 58$ & Med-High & $\mathrm{n} / \mathrm{a}^{* *}$ & 249 & 14 & 2.7 \\
\hline Longmans & 10 & $44 \%$ & $\$ 95$ & Med-High & 2.0 & 211 & 4 & 2.3 \\
\hline Butterworths & 10 & $40 \%$ & $\$ 218$ & Medium & 3.2 & 127 & 4 & 1.4 \\
\hline
\end{tabular}

*Two Taylor \& Francis titles and three Cambridge titles were published after Katz's volume appeared.

**Citation frequency data exists for fewer than half the titles examined.

Taylor \& Francis, for whatever reasons, feels confident pricing its titles in the U.S. market an average $84 \%$ above the U.K. price. How long will it take other British publishers, with titles equally strong or even stronger, to consider whether their titles are not underpriced in the U.S. market? How high, after all, could the U.S. price for Mind or for The Journal of African History rise, regardless of the U.K. price, before American librarians balked? There are already indications that German publishers are watching closely the reactions of the American library community to the pricing strategies of their British counterparts. One, VCH, has taken action. Nor should we expect that American publishers will fail to notice how we respond to this issue.

The real challenge differential pricing raises is not the challenge of inducing British pub- 
lishers to narrow their differential rates. Any narrowing will not likely work to the advantage of their major institutional customers - us. Rather, the real challenge to American librarians is to begin acting more like the consumers we are. We need to begin aggressively to let the market carry our message. That message must be: We will cancel titles that do not meet and continue to meet minimum standards of value. But in order to send that message we need to be designing and sharing with one another mechanisms that will enable us to discern, for our various disciplines, the relative value to our patrons of the products we purchase for their use, and purchase in most cases with public money. The indicators we selected for this study may not be the best ones or even the right ones. Indeed, one will likely need a variety of criteria and indicators for our various disciplines. Yet indicators we will need.

Nor ought we to construct these mechanisms out of a mean-spirited resentment of British publishers and their high differential prices. Frankly, many of us have found these differentials higher than would seem reasonable. Still, publishing is a business. Businesses run on profits. And as people in business for the long run, these publishers surely need sufficient revenues for capital investments, for shoring-up lower-earning but important titles as well as for beginning and shepherding new titles. Without more information, we can only record our puzzlement and look for patterns.

Yet, if we cannot, from the outside, decree what any given title "ought" to cost, we can very well say what for any given title we are willing to pay. The key question for us, then, is not: What's the other fellow paying? Nor is it even: What's that fellow raking in? Rather, it is: Am I getting what I'm paying for? If British titles, in comparison to their counterparts, are indeed Wedgwoods - and many of them surely are - then we ought to expect to pay Wedgwood prices. What we need, though, are ways not only to distinguish the Wedgwoods from the budget brands. We need to know how we will weigh price against value. In any case, what we ought not to do is to continue to distort the journal pricing market, whether through inattention or timidity, by continuing to pay whatever we are asked simply because we are afraid to break a complete run or to do the hard work necessary to convince faculty of the need to balance value against price in our journal collections.

With every renewal we send a message. Every renewal tends both to confirm this year's price and to ground next year's. To that extent we are in a measure responsible for the prices we pay. As managers of other people's resources, before we pay many more additional installments, let's start examining the china.

\section{APPENDIX}

In Tables A1-A7 we list the 108 titles used in our study, along with prices, differentials, and variables met.

\section{REFERENCES}

1. In fact, it is more accurate to speak of a differential range, since the differential will expand or contract with fluctuations in the value of the pound.

2. Royal Society of London. Scientific Information Committer. A Study of the Scientific Information System in the United Kingdom. London: The Society, 1981.

3. Nigel Cross reports that journal publishers will admit to profit margins of $20 \%$. Some speculate margins can be as high as $50 \%$. See his interesting piece: "The Economics of Learned Journal Publishing," Times Literary Supplement (23 November 1984), p. 1348. 
TABLE Al

BIOCHEMICAL SOCIETY, SELECTED TITLES

\begin{tabular}{|c|c|c|c|c|c|c|c|c|}
\hline Title & $\begin{array}{c}1985 \\
\text { U.S. Price* } \\
\text { (Sterling) }\end{array}$ & $\begin{array}{l}1985 \\
\text { U.S. Price } \\
\text { (Dollars) }\end{array}$ & $\begin{array}{l}\text { \%U.S. Rate } \\
\text { Above } \\
\text { U.K. Rate* }\end{array}$ & $\begin{array}{c}\text { Citation } \\
\text { Frequency } \\
\text { (quartile } \\
\text { rank)** }\end{array}$ & $\begin{array}{l}\text { Holding } \\
\text { Libraries } \\
\text { In OCLC }\end{array}$ & $\begin{array}{l}\text { Title } \\
\text { Listed in } \\
\text { Katz?† }\end{array}$ & $\begin{array}{l}\text { Local } \\
\text { Use }\end{array}$ & $\begin{array}{l}\text { Avg. } \\
\text { No. of } \\
\text { Criteria } \\
\text { Met }\end{array}$ \\
\hline $\begin{array}{l}\text { Journal of Embryology \& } \\
\text { Experimental Morphology } \\
\text { Journal of Experimental }\end{array}$ & 125.00 & $\$ 345.00$ & $97 \%$ & Ist & 297 & No & High & 3 \\
\hline Biology & 115.00 & $\$ 315.00$ & $96 \%$ & lst & 355 & Yes & High & 4 \\
\hline $\begin{array}{l}\text { Journal of Cell Science } \\
\text { Journal of Reproduction }\end{array}$ & 150.00 & $\$ 405,00$ & $93 \%$ & 1st & 282 & Yes & High & 4 \\
\hline \& Fertility & 110.00 & $\$ 220.00$ & $43 \%$ & 1st & 221 & No & High & 3 \\
\hline
\end{tabular}

- Calculated at pounds $\$ 1.00=\$ 1.40$ [exchange rate (approx.) as of $5 / 84$ and $9 / 85$ )].

** Citation frequency = Avg. number of times an average article in a journal was cited in another article during 1984 (derived from "impact factor" data and ranking in Science Citation Index and Social Science Citation Index, Journal Citation Reports 1984, Vols. 15 and 7, respectively). Rank indicates where journal stands in relation to other science/social science journals in respect to frequency of citation (i.e. top $25 \%$, second $25 \%$, etc.)

†Katz, Willium A. Magazines for Libraries. New York: Bowker, 1982, 4th ed.

4. For data on the period through 1984 see International Monetary Fund. International Financial Statistics. Supplement on Exchange Rates. Washington, D.C.: IMF, 1985, p. 102.

5. Hamaker, Charles and Astle, Deana. "Recent Pricing Patterns in British Journal Publishing," Library Acquisitions: Practice Theory, 8:4 (1984), 225-232.

6. For citation frequency rankings we have relied upon data which can be found in Science Citation Index 1984. Philadelphia: Institute for Scientific Information, 1985, Vol. 15: Journal Citation Reports and Social Science Citation Index 1984. Philadelphia: Institute for Scientific Information, 1985, Vol. 7: Journal Citation Reports. ISI compiles data on the total number of articles published in a journal during 1982 and 1983 and the number of times articles from those issues were cited in other articles during 1984. They then calculate from this data an "impact factor": that is, they divide the number of citations by the number of articles. This value represents the number of times an average article in the journal was cited during the previous year. In another table ISI lists in rank order by "impact factor" (i.e. citation frequency) all titles tracked. We derived our quartile ranking from this list. Thus a title such as Economic Journal, with a citation frequency ranking of 104th of 1357 titles tracked by SSCI, we have described as ranking in eitation frequency in the first quartile of social science journals. We have been able to furnish citation frequencies only for science and social science titles. ISI does not publish citation frequency data for arts and humanities titles. (Citation frequency measures for such titles may be of more dubious value. To be at all a true measure of title's value to scholars, citation frequency for such titles should be calculated over a much longer period of time.) Finally, our use of ISI's indicators has been extremely broad-scale. More valuable would be comparisons of citation frequency between journals in the same subject areas. Yet even these sorts of comparisons need to be made with caution and a clear sense of the limitations of any such merely numeric measures.

7. To derive data on this variable, we searched each title in OCLC and counted the number of holding libraries. Since some titles have two or more records and since OCLC does not list actual holdings, these figures are approximate. We have assumed, for purposes of this analysis, that libraries which indicated holdings for a title receive that title currently.

8. Katz, William A. Magazines for Libraries. New York: Bowket, 1982, 4th ed.

9. Horn, Judith G. and Lenzini, Rebecea T. "Price Indexes for 1985: U.S. Periodicals," Library Journal (August 1985), p.54. 
TABLE A2

BASIL BLACKWELL, SELECTED TITLES

\begin{tabular}{|c|c|c|c|c|c|c|c|c|}
\hline Title & $\begin{array}{c}1985 \\
\text { U.S. Price* } \\
\text { (Sterling) }\end{array}$ & $\begin{array}{c}1985 \\
\text { U.S. Price } \\
\text { (Dollars) }\end{array}$ & $\begin{array}{c}\text { \%U.S. Rate } \\
\text { Above } \\
\text { U.K. Rate* }\end{array}$ & $\begin{array}{c}\text { Citation } \\
\text { Frequency } \\
\text { (quartile } \\
\text { rank)** }\end{array}$ & $\begin{array}{l}\text { Holding } \\
\text { Libraries } \\
\text { In OCLC }\end{array}$ & $\begin{array}{c}\text { Title } \\
\text { Listed in } \\
\text { Katz?† }\end{array}$ & $\begin{array}{l}\text { Local } \\
\text { Use }\end{array}$ & $\begin{array}{c}\text { Avg. } \\
\text { No. of } \\
\text { Criteria } \\
\text { Met }\end{array}$ \\
\hline Analysis & 11.75 & $\$ 33.00$ & $100 \%$ & $\mathrm{n} / \mathrm{a}$ & 295 & Yes & Medium & 3 \\
\hline Public administration & 27.50 & $\$ 72.50$ & $89 \%$ & $n / a$ & 72 & Yes & Low & 1 \\
\hline $\begin{array}{l}\text { Ratio } \\
\text { Journal of Common }\end{array}$ & 22.95 & $\$ 59.95$ & $86 \%$ & $n / a$ & 165 & Yes & High & 2 \\
\hline Market Studies & 31.00 & $\$ 78.95$ & $82 \%$ & 4 th & 235 & Yes & Medium & 3 \\
\hline Universities Quarterly & 24.00 & $\$ 61.00$ & $81 \%$ & $n / a$ & 139 & No & Medium & 1 \\
\hline $\begin{array}{l}\text { German Life \& Letters } \\
\text { Oxford Bulletin of }\end{array}$ & 32.00 & $\$ 80.00$ & $79 \%$ & $n / a$ & 226 & No & Medium & 2 \\
\hline $\begin{array}{l}\text { Economics \& Statistics } \\
\text { Journal for the Theory }\end{array}$ & 33.50 & $\$ 83.90$ & $79 \%$ & 3rd & 155 & Yes & High & 2 \\
\hline of Social Behaviour & 32.75 & $\$ 81.00$ & $76 \%$ & 2nd & 182 & Yes & High & 3 \\
\hline World Economy & 42.00 & $\$ 100.00$ & $71 \%$ & 2nd & 84 & No & Medium & 2 \\
\hline Philosophical Books & 23.50 & $\$ 55.50$ & $69 \%$ & $\mathrm{n} / \mathrm{a}$ & 156 & Yes & Medium & 2 \\
\hline $\begin{array}{l}\text { Metaphilosophy } \\
\text { Journal of Industrial }\end{array}$ & 28.00 & $\$ 65.00$ & $66 \%$ & $\mathrm{n} / \mathrm{a}$ & 185 & Yes & High & 2 \\
\hline Economics & 29.00 & $\$ 65.75$ & $62 \%$ & 2nd & 289 & Yes & High & 4 \\
\hline $\begin{array}{l}\text { Philosophical Quarterly } \\
\text { British Journal of }\end{array}$ & 26.00 & $\$ 57.50$ & $58 \%$ & $\mathrm{n} / \mathrm{a}$ & 316 & Yes & Medium & 3 \\
\hline $\begin{array}{l}\text { Industrial Relations } \\
\text { Bulletin of Economic }\end{array}$ & 19.50 & $\$ 42.50$ & $56 \%$ & 3 rd & 135 & Yes & High & 2 \\
\hline $\begin{array}{l}\text { Research } \\
\text { British Journal of }\end{array}$ & 27.00 & $\$ 58.65$ & $55 \%$ & $\mathrm{n} / \mathrm{a}$ & 80 & No & Medium & 1 \\
\hline Educational Studies & 39.50 & $\$ 76.75$ & $39 \%$ & 3rd & 225 & No & Low & 1 \\
\hline
\end{tabular}

TABLE A3

BUTTERWORTHS, SELECTED TITLES

\begin{tabular}{|c|c|c|c|c|c|c|c|c|}
\hline Title & $\begin{array}{c}1985 \\
\text { U.S. Price* } \\
\text { (Sterling) }\end{array}$ & $\begin{array}{c}1985 \\
\text { U.S. Price } \\
\text { (Dollars) }\end{array}$ & $\begin{array}{c}\text { \% U.S. Rate } \\
\text { Above } \\
\text { U.K. Rate* }\end{array}$ & $\begin{array}{c}\text { Citation } \\
\text { Frequency } \\
\text { (quartile } \\
\text { rank)** }\end{array}$ & $\begin{array}{l}\text { Holding } \\
\text { Libraries } \\
\text { In OCLC }\end{array}$ & $\begin{array}{c}\text { Title } \\
\text { Listed in } \\
\text { Katz?† }\end{array}$ & $\begin{array}{c}\text { Local } \\
\text { Use }\end{array}$ & $\begin{array}{l}\text { Avg. } \\
\text { No. of } \\
\text { Criteria } \\
\text { Met }\end{array}$ \\
\hline \multicolumn{9}{|l|}{ Applied Mathematical } \\
\hline Modelling & 115.00 & $\$ 230.00$ & $43 \%$ & $4 \mathrm{th}$ & 117 & No & Medium & 1 \\
\hline Cryogenics & 168.00 & $\$ 336.00$ & $43 \%$ & 3rd & 188 & No & High & 1 \\
\hline Energy economics & 88.00 & $\$ 176.00$ & $43 \%$ & 3rd & 80 & Yes & Medium & 2 \\
\hline Engineering Structures & 85.00 & $\$ 170.00$ & $43 \%$ & $3 \mathrm{rd}$ & 74 & No & Low & 0 \\
\hline Fue] & 250.00 & $\$ 500.00$ & $43 \%$ & 1st & 128 & Yes & High & 3 \\
\hline \multicolumn{9}{|l|}{ Studies in Comparative } \\
\hline Communism & 17.50 & $\$ 35.00$ & $43 \%$ & $4 \mathrm{th}$ & 260 & Yes & High & 3 \\
\hline Ultrasonics & 75.00 & $\$ 150.00$ & $43 \%$ & 3rd & 138 & No & Medium & 1 \\
\hline Food rolicy & 79.00 & $\$ 153.00$ & $38 \%$ & $4 \mathrm{th}$ & 67 & No & Low & 0 \\
\hline Data Processing & 82.00 & $\$ 148.00$ & $29 \%$ & $4 \mathrm{th}$ & 99 & Yes & High & 2 \\
\hline Computer-aided Design & 158.00 & $\$ 284.00$ & $29 \%$ & 3 rd & 117 & No & High & 1 \\
\hline
\end{tabular}


TABLE A4

CAMBRIDGE UNIVERSITY PRESS, SELECTED TITLES

\begin{tabular}{|c|c|c|c|c|c|c|c|c|}
\hline Title & $\begin{array}{c}1985 \\
\text { U.S. Price } \\
\text { (Sterling) }\end{array}$ & $\begin{array}{c}1985 \\
\text { U.S. Price } \\
\text { (Dollars) }\end{array}$ & $\begin{array}{c}\% \\
\text { U.S. Rate } \\
\text { Above } \\
\text { U.K. Rate }\end{array}$ & $\begin{array}{l}\text { Citation } \\
\text { Frequency } \\
\text { (quartile } \\
\text { rank) }\end{array}$ & $\begin{array}{l}\text { Holding } \\
\text { Libraries } \\
\text { In OCLC }\end{array}$ & $\begin{array}{c}\text { Title } \\
\text { Listed in } \\
\text { Katz? } \dagger\end{array}$ & $\begin{array}{l}\text { Local } \\
\text { Use }\end{array}$ & $\begin{array}{l}\text { Avg. } \\
\text { No. of } \\
\text { Criteria } \\
\text { Met }\end{array}$ \\
\hline \multicolumn{9}{|l|}{ Journal of American } \\
\hline Studies & 28.00 & $\$ 74.00$ & $89 \%$ & $\mathrm{n} / \mathrm{a}$ & 380 & Yes & High & 3 \\
\hline $\begin{array}{l}\text { Journal of Social Policy } \\
\text { British Journal of }\end{array}$ & 38.00 & $\$ 98.00$ & $84 \%$ & 2nd & 177 & Yes & Medium & 3 \\
\hline $\begin{array}{l}\text { Nutrition } \\
\text { Nutrition Society, }\end{array}$ & 110.00 & $\$ 280.00$ & $82 \%$ & 1st & 195 & Yes & High & 3 \\
\hline $\begin{array}{l}\text { Proceedings } \\
\text { British Journal of }\end{array}$ & 55.00 & $\$ 104.00$ & $82 \%$ & 1st & 161 & Yes & High & 3 \\
\hline Political Science & 41.00 & $\$ 104.00$ & $81 \%$ & Ist & 277 & Yes & High & 4 \\
\hline Geological Magazine & 63.00 & $\$ 160.00$ & $81 \%$ & 2nd & 195 & Yes & High & 3 \\
\hline Journal of Hygiene & 39.00 & $\$ 97.50$ & $79 \%$ & 1 st & 143 & No & High & 2 \\
\hline Laser and Particle Beams & 54.00 & $\$ 135.00$ & $79 \%$ & $\mathbf{n} / \mathbf{a}$ & 40 & $\mathrm{n} / \mathrm{a}$ & $n / a$ & $\mathbf{0}$ \\
\hline Philosophy & 48.00 & $\$ 120.00$ & $79 \%$ & $\mathrm{n} / \mathrm{a}$ & 330 & Yes & Medium & 3 \\
\hline \multicolumn{9}{|l|}{ Journal of Latin American } \\
\hline Studies & 28.00 & $\$ 70.00$ & $79 \%$ & 3 rd & 335 & Yes & High & 3 \\
\hline Journal of Plasma Physics & 80.00 & $\$ 197.00$ & $76 \%$ & 2nd & 124 & Yes & Medium & 3 \\
\hline New Testament Studies & 28.00 & $\$ 69.00$ & $76 \%$ & $\mathrm{n} / \mathrm{a}$ & 243 & Yes & High & 3 \\
\hline Historical Journal & 48.00 & $\$ 118.00$ & $76 \%$ & $\mathrm{n} / \mathbf{a}$ & 302 & Yes & High & 3 \\
\hline Regional Studies & 53.00 & $\$ 130.00$ & $75 \%$ & 1st & 165 & Yes & Medium & 3 \\
\hline Parasitology & 102.00 & $\$ 250.00$ & $75 \%$ & 1st & 205 & No & High & 3 \\
\hline Journal of Anatomy & 119.00 & $\$ 290.00$ & $74 \%$ & 2nd & 187 & No & High & 2 \\
\hline Psychological Medicine & 80.00 & $\$ 195.00$ & $74 \%$ & 1st & 120 & Yes & High & 3 \\
\hline Genetical Research & 72.00 & $\$ 175.00$ & $74 \%$ & 1st & 249 & Yes & High & 4 \\
\hline Language Teaching & 27.00 & $\$ 65.00$ & $72 \%$ & $\mathrm{n} / \mathrm{a}$ & 214 & Yes & Medium & 3 \\
\hline Journal of Linguistics & 25.00 & $\$ 60.00$ & $71 \%$ & 2nd & 288 & Yes & High & 4 \\
\hline Annals of Human Genetics & 44.00 & $\$ 105.00$ & $71 \%$ & 1st & 197 & No & High & 2 \\
\hline Religious Studies & 44.00 & $\$ 105.00$ & $71 \%$ & $\mathrm{n} / \mathrm{a}$ & 321 & Yes & Medium & 3 \\
\hline Journal of Physiology & 435.00 & $\$ 1030.00$ & $69 \%$ & Ist & 380 & Yes & Medium & 4 \\
\hline Journal of African History & 35.00 & $\$ 83.00$ & $69 \%$ & 2nd & 451 & Yes & High & 4 \\
\hline Journal of Fluid Mechanics & 312.00 & $\$ 735.00$ & $69 \%$ & 1st & 219 & Yes & High & 4 \\
\hline $\begin{array}{l}\text { Modern Asian Studies } \\
\text { British Mycological Society, }\end{array}$ & 47.00 & $\$ 110.00$ & $67 \%$ & 3 rd & 191 & Yes & High & 2 \\
\hline \multicolumn{2}{|l|}{ British Mycological Society, } & $\$ 187.50$ & $67 \%$ & 2nd & & No & High & 2 \\
\hline \multicolumn{9}{|l|}{ Journal of Ecclesiastical } \\
\hline History & 45.00 & $\$ 105.00$ & $66 \%$ & $\mathrm{n} / \mathrm{a}$ & 261 & Yes & High & 3 \\
\hline Economic Journal & 45.00 & $\$ 100.00$ & $59 \%$ & 1st & 502 & Yes & High & 4 \\
\hline \multicolumn{9}{|l|}{ British Journal of } \\
\hline Music Education & 16.00 & $\$ 35.00$ & $56 \%$ & $\mathrm{n} / \mathrm{a}$ & 37 & $\mathrm{n} / \mathrm{a}$ & $\mathrm{n} / \mathrm{a}$ & 0 \\
\hline Journal of Child Language & 41.00 & $\$ 89.00$ & $55 \%$ & 2nd & 262 & Yes & High & 4 \\
\hline BioEssays & 63.00 & $\$ 135.00$ & $53 \%$ & $\mathrm{n} / \mathrm{a}$ & 48 & $\mathrm{n} / \mathrm{a}$ & $\mathrm{n} / \mathrm{a}$ & 0 \\
\hline \multicolumn{9}{|l|}{ International Journal of } \\
\hline Middle East Studie & 42.00 & $\$ 80.00$ & $36 \%$ & 3rd & 257 & Yes & High & 3 \\
\hline $\begin{array}{l}\text { Language in Society } \\
\text { Comparative Studies in }\end{array}$ & 40.00 & $\$ 70.00$ & $25 \%$ & Ist & 225 & Yes & High & 4 \\
\hline \multicolumn{9}{|l|}{ Comparative Studies in } \\
\hline
\end{tabular}


TABLE AS

LONGMANS, SELECTED TITLES

\begin{tabular}{|c|c|c|c|c|c|c|c|c|}
\hline Title & $\begin{array}{c}1985 \\
\text { U.S. Price } \\
\text { (Sterling) }\end{array}$ & $\begin{array}{c}1985 \\
\text { U.S. Price } \\
\text { (Dollars) }\end{array}$ & $\begin{array}{c}\% \\
\text { U.S. Rate } \\
\text { Above } \\
\text { U.K. Rate }\end{array}$ & $\begin{array}{l}\text { Citation } \\
\text { Frequency } \\
\text { (quartile } \\
\text { rank) }\end{array}$ & $\begin{array}{l}\text { Holding } \\
\text { Llbraries } \\
\text { In OCLC }\end{array}$ & $\begin{array}{c}\text { Title } \\
\text { Listed in } \\
\text { Katz?† }\end{array}$ & $\begin{array}{l}\text { Local } \\
\text { Use }\end{array}$ & $\begin{array}{l}\text { Avg. } \\
\text { No. of } \\
\text { Criteria } \\
\text { Met }\end{array}$ \\
\hline \multicolumn{9}{|c|}{ Keesings Contemporary } \\
\hline Archives & 70.00 & $\$ 179.00$ & $83 \%$ & $\mathrm{n} / \mathrm{a}$ & 308 & Yes & High & 4 \\
\hline \multicolumn{9}{|l|}{ British Journal of } \\
\hline Urolosy & 32.00 & $\$ 68.00$ & $51 \%$ & 2nd & 149 & No & High & 2 \\
\hline Urban Studies & 32.00 & $\$ 64.00$ & $43 \%$ & 1st & 250 & Yes & Medium & 4 \\
\hline Tissue and Cell & 120.00 & $\$ 240.00$ & $43 \%$ & 2nd & 176 & No & Medium & 2 \\
\hline Tubercle & 38.00 & $\$ 75.00$ & $41 \%$ & 2nd & 76 & No & High & 2 \\
\hline Soviet Studies & 28.00 & $\$ 55.00$ & $41 \%$ & 2nd & 330 & Yes & High & 4 \\
\hline \multicolumn{9}{|l|}{ British Journal of } \\
\hline Addiction & 40.00 & $\$ 76.00$ & $36 \%$ & Ist & 63 & No & High & 2 \\
\hline \multicolumn{9}{|l|}{ English Historical } \\
\hline Review & 29.00 & $\$ 55.00$ & $36 \%$ & $\mathrm{n} / \mathrm{a}$ & 566 & Yes & Medium & 3 \\
\hline Paraplegia & 45.00 & $\$ 86.00$ & $36 \%$ & 3 rd & 75 & No & Low & 0 \\
\hline \multicolumn{9}{|l|}{ British Journal of } \\
\hline Plastic Surgery & 30.00 & $\$ 55.00$ & $31 \%$ & 3rd & 112 & No & High & 1 \\
\hline
\end{tabular}

TABLE A6

OXFORD UNIVERSITY PRESS, SELECTED TITLES

\begin{tabular}{|c|c|c|c|c|c|c|c|c|}
\hline Title & $\begin{array}{c}1985 \\
\text { U.S. Price } \\
\text { (Sterling) }\end{array}$ & $\begin{array}{c}1985 \\
\text { U.S. Price } \\
\text { (Dollars) }\end{array}$ & $\begin{array}{c}\% \\
\text { U.S. Rate } \\
\text { Above } \\
\text { U.K. Rate }\end{array}$ & $\begin{array}{l}\text { Citation } \\
\text { Frequency } \\
\text { (quartlle } \\
\text { rank) }\end{array}$ & $\begin{array}{l}\text { Holding } \\
\text { Libraries } \\
\text { In OCLC }\end{array}$ & $\begin{array}{c}\text { Title } \\
\text { Listed in } \\
\text { Katz?† }\end{array}$ & $\begin{array}{l}\text { Local } \\
\text { Use }\end{array}$ & $\begin{array}{l}\text { Avg. } \\
\text { No. of } \\
\text { Criteria } \\
\text { Met }\end{array}$ \\
\hline \multicolumn{9}{|l|}{ English Language } \\
\hline $\begin{array}{l}\text { Classical Review } \\
\text { Journal of Southern }\end{array}$ & 19.00 & $\$ 45.00$ & $69 \%$ & $\mathrm{n} / \mathrm{a}$ & 325 & Yes & High & 3 \\
\hline African Studies & 19.00 & $\$ 45.00$ & $69 \%$ & $n / a$ & 82 & Yes & High & 2 \\
\hline Classical Quarterly & 21.00 & $\$ 49.00$ & $66 \%$ & $\mathrm{n} / \mathrm{a}$ & 267 & Yes & High & 3 \\
\hline Cambridge Quarterly & 20.00 & $\$ 45.00$ & $61 \%$ & $\mathrm{n} / \mathrm{a}$ & 190 & Yes & Medium & 2 \\
\hline Greece and Rome & 14.00 & $\$ 30.00$ & $53 \%$ & $\mathrm{n} / \mathrm{a}$ & 237 & Yes & High & 3 \\
\hline Oxford Economic Papers & 29.00 & $\$ 60.00$ & $49 \%$ & 2nd & 307 & Yes & High & 4 \\
\hline $\begin{array}{l}\text { British Journal of } \\
\text { Aesthetics }\end{array}$ & & & & $\mathfrak{n} / \mathfrak{a}$ & & & & 2 \\
\hline $\begin{array}{l}\text { Parliamentary Affairs } \\
\text { Journal of Experimental }\end{array}$ & 24.00 & $\$ 50.00$ & $49 \%$ & 4 th & 228 & Yes & Medium & 3 \\
\hline Botany & 110.00 & $\$ 230.00$ & $49 \%$ & 1st & 230 & Yes & High & 4 \\
\hline Review of English Studies & 24.00 & $\$ 50.00$ & $49 \%$ & $\mathbf{n} / \mathbf{a}$ & 494 & Yes & High & 3 \\
\hline $\begin{array}{l}\text { African Affairs } \\
\text { Theatre Research }\end{array}$ & 3000 & $\$ 45.00$ & $46 \%$ & 3rd & 231 & Yes & High & 3 \\
\hline International Quarterly & 22.00 & $\$ 45.00$ & $46 \%$ & $n / a$ & 164 & Yes & Low & 1 \\
\hline Mind & 16.00 & $\$ 32.50$ & $45 \%$ & $n / a$ & 389 & Yes & High & 3 \\
\hline
\end{tabular}


TABLE A7

TAYLOR \& FRANCIS, SELECTED TITLES

\begin{tabular}{|c|c|c|c|c|c|c|c|c|}
\hline Title & $\begin{array}{l}1985 \\
\text { U.S. Price } \\
\text { (Sterling) }\end{array}$ & $\begin{array}{c}1985 \\
\text { U.S. Price } \\
\text { (Dollars) }\end{array}$ & $\begin{array}{c}\% \\
\text { U.S. Rate } \\
\text { Above } \\
\text { U.K. Rate }\end{array}$ & $\begin{array}{l}\text { Citation } \\
\text { Frequency } \\
\text { (quartile } \\
\text { rank) }\end{array}$ & $\begin{array}{l}\text { Holding } \\
\text { Libraries } \\
\text { In OCLC }\end{array}$ & $\begin{array}{c}\text { Title } \\
\text { Listed in } \\
\text { Katz?† }\end{array}$ & $\begin{array}{l}\text { Local } \\
\text { Use }\end{array}$ & $\begin{array}{l}\text { Avg. } \\
\text { No. of } \\
\text { Criteria } \\
\text { Met }\end{array}$ \\
\hline $\begin{array}{l}\text { Annals of Science } \\
\text { International Journal of }\end{array}$ & 87.00 & $\$ 260.00$ & $114 \%$ & 2nd & 174 & Yes & Medium & 3 \\
\hline Production Research & 99.00 & $\$ 294.00$ & $112 \%$ & 4th & 138 & No & High & 1 \\
\hline $\begin{array}{l}\text { History of Education } \\
\text { Maritime Policy and }\end{array}$ & 44.00 & $\$ 131.00$ & $112 \%$ & $\mathrm{n} / \mathrm{a}$ & 41 & No & Low & 0 \\
\hline $\begin{array}{l}\text { Management } \\
\text { Ergonomics }\end{array}$ & $\begin{array}{r}59.00 \\
112.00\end{array}$ & $\begin{array}{l}\$ 170.00 \\
\$ 320.00\end{array}$ & $\begin{array}{l}106 \% \\
104 \%\end{array}$ & $\begin{array}{l}\mathrm{n} / \mathrm{a} \\
\text { 2nd }\end{array}$ & $\begin{array}{r}39 \\
223\end{array}$ & $\begin{array}{l}\text { Yes } \\
\text { Yes }\end{array}$ & $\begin{array}{l}\text { Medium } \\
\text { High }\end{array}$ & $\begin{array}{l}2 \\
4\end{array}$ \\
\hline Annals of Human & & & & & & & & \\
\hline $\begin{array}{l}\text { Biology } \\
\text { Contemporary Physics } \\
\text { International Journal of }\end{array}$ & $\begin{array}{l}67.00 \\
65.00\end{array}$ & $\begin{array}{l}\$ 190.00 \\
\$ 184.00\end{array}$ & $\begin{array}{l}103 \% \\
102 \%\end{array}$ & $\begin{array}{l}\text { 2nd } \\
1 \mathrm{st}\end{array}$ & $\begin{array}{r}71 \\
290\end{array}$ & $\begin{array}{l}\text { No } \\
\text { Yes }\end{array}$ & $\begin{array}{l}\text { High } \\
\text { High }\end{array}$ & $\begin{array}{l}2 \\
4\end{array}$ \\
\hline $\begin{array}{l}\text { Systems Science } \\
\text { International Journal of }\end{array}$ & 200.00 & $\$ 560.00$ & $100 \%$ & 2nd & 85 & Yes & High & 3 \\
\hline $\begin{array}{l}\text { Electronics } \\
\text { Optica Acta }\end{array}$ & $\begin{array}{l}192.00 \\
178.00\end{array}$ & $\begin{array}{l}\$ 530.00 \\
\$ 490.00\end{array}$ & $\begin{array}{l}97 \% \\
96 \%\end{array}$ & $\begin{array}{l}3 \text { rd } \\
\text { 2nd }\end{array}$ & $\begin{array}{r}91 \\
118\end{array}$ & $\begin{array}{l}\text { No } \\
\text { Yes }\end{array}$ & $\begin{array}{l}\text { Medium } \\
\text { Medium }\end{array}$ & 1 \\
\hline $\begin{array}{l}\text { International Journal } \\
\text { of Mathematical } \\
\text { Education }\end{array}$ & 65.00 & $\$ 176.00$ & $94 \%$ & $\mathrm{n} / \mathrm{a}$ & 178 & No & Medium & 1 \\
\hline $\begin{array}{l}\text { International Journal } \\
\text { of Control }\end{array}$ & 260.00 & $\$ 690.00$ & $89 \%$ & 2nd & 137 & No & High & 2 \\
\hline $\begin{array}{l}\text { Molecular Physics } \\
\text { Journal of Natural }\end{array}$ & 348.00 & $\$ 860.00$ & $77 \%$ & 1st & 205 & No & Medium & 3 \\
\hline $\begin{array}{l}\text { History } \\
\text { International Journal of } \\
\text { Radiation Biology \& }\end{array}$ & 173.00 & $\$ 380.00$ & $57 \%$ & 3rd & 112 & Yes & High & 2 \\
\hline Related Studies in ... & 209.00 & $\$ 460.00$ & $57 \%$ & 2nd & 154 & No & High & 2 \\
\hline Xenobiotica & 168.00 & $\$ 370.00$ & $57 \%$ & 1st & 83 & No & Medium & 2 \\
\hline $\begin{array}{l}\text { Behavior and Infor- } \\
\text { mation Technology } \\
\text { Journal of Garden }\end{array}$ & 45.00 & $\$ 98.00$ & $56 \%$ & $\mathrm{n} / \mathbf{a}$ & 41 & $\mathrm{n} / \mathrm{a}$ & Medium & 1 \\
\hline History & 45.00 & $\$ 96.00$ & $52 \%$ & $\mathrm{n} / \mathrm{a}$ & 78 & $\mathrm{n} / \mathrm{a}$ & Low & 0 \\
\hline History of Photography & 38.00 & $\$ 60.00$ & $16 \%$ & $\mathrm{n} / \mathrm{a}$ & 165 & Yes & Low & 1 \\
\hline
\end{tabular}

